\title{
Sterol Content in Cigarette Tobacco and Smoke*
}

\author{
by Amber L. S. Cheng \\ Plant Genetics and Germplasm Institute, Agricultural Research Center, \\ Agricultural Research Service, \\ United States Department of Agriculture, Beltsville, Maryland, USA
}

\section{INTRODUCTION}

The presence of sterols in cigarette tobacco and cigarette smoke in the free form or as esters and bound as glycosides is well established $(1,2,3,4)$. However, knowledge of the quantitative transfer of the various forms of sterols from cigarette tobacco to cigarette smoke has been limited. Recently their quantitative transfer from cigarette tobacco to cigarefte smoke has been studied (5). Since the temperature at the combustion zone is approximately $600^{\circ} \mathrm{C}-900^{\circ} \mathrm{C}(6)$, various forms of sterols found in cigarette smoke may not represent the original sterol forms of the cigarette tobaccos. Therefore, further investigation of the sterol composition of cigarette tobacco and cigarette smoke was undertaken. ${ }^{14} \mathrm{C}$-labeled cholesterol and $\beta$-sitosterol were incorporated into cigarettes and their presence in mainstream smoke was studied. In addition, a comparison was made between various forms of sterols as well as individual sterols in cigarette tobacco and their mainstream smoke.

\section{EXPERIMENTAL}

Cigarette smoking: Non-filtered cigarettes (Code IRI) were purchased from the University of Kentucky, Tobacco and Health Research Institute, Lexington, Kentucky. Each cigarette was $85 \mathrm{~mm}$ in length and weighed an average of $x .06 \mathrm{~g}$. Tested cigarettes were equilibrated at $74^{\circ} \mathrm{F}$ temperature and $60 \%$ relative humidity for $72 \mathrm{hr}$. before being used. Smoking condition provided a 2-second puff of $35 \mathrm{ml}$ at 60-second intervals. The cigarettes were smoked to a butt length of $23 \mathrm{~mm}$. After each cigarefte was extinguished, an additional puff was drawn through the system in order to collect any residual smoke. The cigarette smoke was passed directly into a series of two ice-cooled traps containing acetone.

Sterol extraction: Mainstream smoke collected in acetone was transferred to a flask. Butts and ashes from the cigarettes were collected separately and extracted with acetone for $\mathbf{2 4} \mathrm{hr}$. in a Soxhlet appara-

\footnotetext{
- Received for publisation: Ist September, 1972.
}

tus**. Acetone was removed in pacuo. The residues were saponified with $1 \%$ of alc. $\mathrm{H}_{2} \mathrm{SO}_{4}$, followed by $10 \%$ alc. $\mathrm{KOH}$. Free sterols in non-saponifiable fractions were extracted with petroleum ether and were then precipitated with digitonin to form sterol digitonides (7). The sterol content was obtained by multiplying the weight of digitonides by a factor of 0.253 (8).

Cigarette samples: A chloroform solution of cholesterol$4^{-14} \mathrm{C}$ or $\beta$-sitosterol-4-14 $\mathrm{C}$ (Radiochemical Centre Amersham/Searle Corporation, Ill., USA) was injected into $62 \mathrm{~mm}$ length of a cigarette with a Hamilton syringe ${ }^{* *}$. The ${ }^{14} \mathrm{C}$-labeled solution was expelled as the needle was withdrawn, and left the remaining $23 \mathrm{~mm}$ length of the cigarette uncontaminated. Chloroform was evaporated from the cigarettes at room temperature and cigarettes were then equilibrated to $60 \%$ relative humidity. The treated ends of cigarettes were smoked in a single-port automatic smoking mahine** (Cigarette Components Ltd.). Each sample of smoke condensates and butts was collected from to cigarettes, whereas the ashes to be analyzed were the combined ashes from three samples or 30 cigarettes. Two separate experiments were carried out. The ${ }^{14} \mathrm{C}$ isotope treatments, smoking procedures, sterol extractions, and sterol content calculations were the same for these two experiments. However, the radioactivity was assayed in different sterol forms. In Experiment A, free sterols were regenerated from sterol digitonides by decomposing the complex with pyridine and extracting sterols into ether. Ether was removed with $\mathrm{N}_{2}$. The residue containing radioactivity of the free sterols was dissolved in toluene. In Experiment B, the radioactivity was directly assayed in a methanolic solution of sterol digitonides. The radioactivities of Experiments $A$ and $B$ were measured in a scintillation fluid consisting of $0.015 \%$ of 1,4 -bis-[2-(5-phenyl-oxazolyl)]-benzene (POPOP) and $0.3 \%$ of 2,5-diphenyloxazole (PPO) in toluene by a liquid scintillation spectrometer (Packard Model $3375^{* *}$ ). All counts were corrected for background and instrument efficiency. The trapped smoke condensates, butts and ashes from each sample of to ciga-

\footnotetext{
** Mention of a tradenark or proprietary product does nor constitute a guarantee of watrancy of the product by the U.S. Department of Agriculture, and does not imply its approval to the exclusion of other products that may also be suitable.
} 
rettes (non-radioactive) were also collected. Sterol extractions and isolations were performed in the same manner as with the ${ }^{14} \mathrm{C}$-labeled cigarettes. These samples were used for background radioactivity measurement.

For the determination of different forms of sterols (free sterol, steryl esters, and steryl glycosides), the cigarettes were smoked in a multi-port smoking machine+ (W. R. Mason and Co.). The acetone extracts from shredded leaves of 100 non-smoked cigarettes and trapped smoke condensates from an equal number of cigarettes smoked were used. Acetone extracts were equally divided into 3 portions. Sterols were analyzed as described by Stedman and Rusaniwskyj (7). Values for free and total sterols were obtained directly, while those of steryl esters and steryl glycosides were calculated from the three aliquots.

For the determination of individual sterols (cholesterol, campesterol, B-sitosterol and stigmasterol), 200 cigarettes were smoked in a multi-port smoking machine+ (W. R. Mason and Co.). Trapped smoke condensates, butts, ashes and wrapping papers from butts were analyzed separately for sterol content. Unburned shredded tobacco leaves from 20 cigarettes were analyzed separately and used as control. The procedures for sterol extractions and sterol isolations were the same as that described above. The individual sterols obtained from cigarette tobaccos and cigarette smoke were measured by gas-liquid chromatography ( 9 ).

\section{RESULTS AND DISCUSSION}

${ }^{14} \mathrm{C}$-cholesterol and ${ }^{14} \mathrm{C}-\beta$-sitosterol injected cigarettes were smoked. The activities in trapped smoke condensates, butts and ashes from mainstream smoke were de- termined, as shown in Table 1 . The recovery of ${ }^{14} \mathrm{C}$ sterols measured as free sterols (Experiment A) agrees well with that of ${ }^{14} \mathrm{C}$-sterols measured as sterol digitonides (Experiment B). The average transfer of ${ }^{14} \mathrm{C}$-labeled cholesterol to mainstream smoke was $20.27 \%$, of which $16.25 \%$ was in trapped smoke condensates and $4.02 \%$ in butts; only $0.004 \%$ was in ashes. The average transfer of ${ }^{14} \mathrm{C}$-labeled $\beta$-sitosterol to mainstream smoke was $16.20 \%$, of which $13.11 \%$ was in trapped smoke condensates and $3.09 \%$ in butts. Ashes contained $0.007 \%$. ${ }^{14} \mathrm{C}$-labeled products recovered from smoke condensates and butts were identified by comparison of reversed phase thin-layer chromatographic (10) patterns with those of authentic cholesterol and $\beta$-sitosterol. The results indicate that sterol constituents of cigarette tobacco were chemically unchanged and carry over into mainstream smoke. A significant amount of ${ }^{14} \mathrm{C}$-labeled sterols was vaporized and entrapped in butts. The radioactivity in ashes was so low that the quantitative data were not significant. The radioactivity in ashes must have come from the contamination of tobacco stubs during each removal of butts after smoking. In acetone trapped smoke condensates, the level of cholesterol was higher $(16.25 \%$ compared to $13.9 \%$ ) and the level of $\beta$-sitosterol was lower (13.11 \% compared to $18.9 \%$ ) than that found by Grunwald et al. (5). The activities of cholesterol and $\beta$-sitosterol in smoke condensates and butts of this study indicate that these sterols are solely from ${ }^{14} \mathrm{C}$-labeled injected sterol cigarettes. Regarding the weight data, up to $17.63 \%$ of total sterol was trapped in smoke condensates and $0.45 \%$ was deposited in butts. The remaining $82 \%$ of sterols may have vaporized as sidestream smoke or converted into other products.

Table 1. Total and radioactive sterols in cigarette smoke.

\begin{tabular}{|c|c|c|c|c|}
\hline & \multirow{2}{*}{\multicolumn{2}{|c|}{ Experiment $A^{*}$}} & & \\
\hline & & & \multicolumn{2}{|c|}{ Experiment $\mathrm{B}^{*}$} \\
\hline & Welght** & Recovered activity & Weight ${ }_{\%}^{* \star}$ & $\underset{\%}{\text { Recovered activity }}$ \\
\hline \multicolumn{5}{|c|}{ Cholesterol-4-14C-Injected cigarettes } \\
\hline Smoke condensate & $\begin{array}{l}17.87 \\
18.57 \\
17.92\end{array}$ & $\begin{array}{l}16.15 \\
15.59 \\
15.72\end{array}$ & $\begin{array}{l}18.40 \\
18.57 \\
19.27\end{array}$ & $\begin{array}{l}16.41 \\
16.83 \\
16.79\end{array}$ \\
\hline Butts & $\begin{array}{l}0.20 \\
0.30 \\
0.30\end{array}$ & $\begin{array}{l}4.59 \\
4.32 \\
4.44\end{array}$ & $\begin{array}{l}0.46 \\
0.23 \\
0.53\end{array}$ & $\begin{array}{l}3.51 \\
3.93 \\
3.35\end{array}$ \\
\hline $\begin{array}{l}\text { Ashes } \\
\left.\beta \text {-sltosterol-4- }{ }^{14} \mathrm{C}-\ln \right]\end{array}$ & \multicolumn{4}{|c|}{$\beta$-siltosterol-4-14C-Injected clgarettes } \\
\hline Smoke condensate & $\begin{array}{l}15.07 \\
15.94 \\
18.35\end{array}$ & $\begin{array}{l}12.57 \\
13.00 \\
14.01\end{array}$ & $\begin{array}{l}17.79 \\
15.06 \\
16.47\end{array}$ & $\begin{array}{l}12.67 \\
12.64 \\
13.77\end{array}$ \\
\hline Butts & $\begin{array}{l}0.45 \\
0.15 \\
0.13\end{array}$ & $\begin{array}{l}3.38 \\
3.30 \\
3.19\end{array}$ & $\begin{array}{l}0.51 \\
0.78 \\
0.70\end{array}$ & $\begin{array}{l}2.64 \\
3.14 \\
2.88\end{array}$ \\
\hline Ashes & - & - & 0.06 & 0.007 \\
\hline
\end{tabular}


Table 2. Composition of three sterol forms in clgarette tobaccos and trapped smoke condensates.

\begin{tabular}{l|c|c}
\hline Forms & $\begin{array}{c}\text { Cigarette tobaccos } \\
\%\end{array}$ & $\begin{array}{c}\text { Cigarette tobacco } \\
\text { smoke, \% }\end{array}$ \\
\hline Free & 42.24 & 74.60 \\
As esters & 52.01 & 12.20 \\
As glycosides & 5.74 & 13.20 \\
\hline
\end{tabular}

The relative amount of the three forms of sterols in cigarette tobacco and its trapped smoke condensate are shown in Table 2. Fractions of free sterols and steryl glycosides were higher while the fraction of esters was lower in trapped smoke condensates as compared to unburned cigarette tobacco. The increase of free sterols in smoke condensate that was found may have resulted from the deacylation of steryl esters. When hydrolysis of acylated steryl glycosides smoke condensates as compared to cigarette tobacco. Comparison of four individual sterols (cholesterol, campesterol, stigmasterol and $\beta$-sitosterol) was studied in cigarette tobacco and cigarette smoke (smoke condensates, butts, wrapping papers from butts). A slight increase of cholesterol was noted in smoke condensates and wrapping papers from butts.

\section{ZUSAMMENFASSUNG}

Nachdem Cigaretten mit Cholesterin-4- ${ }^{14} \mathrm{C}$ und $\beta$-Sitosterin-4- ${ }^{14} \mathrm{C}$ dotiert worden waren, wurde das Vorkommen dieser Verbindungen im Hauptstromrauch untersucht. ${ }^{14} \mathrm{C}$-markiertes Cholesterin ging $\mathrm{zu} 20,27 \%$ in den Hauptstromrauch über; $16,25 \%$ wurden im aufgefangenen Rauchkondensat, 4,02\% im Stummel und nur $0,004 \%$ in der Asche nachgewiesen. Der Ubergang des ${ }^{14} \mathrm{C}$-markierten $\beta$-Sitosterin in den Hauptstrom-

Table 3. GLC analysls of Individual sterols In cigarette tobaccos and their trapped mainstream smoke.

\begin{tabular}{l|cc|c|c}
\hline \multicolumn{1}{c|}{ Samples } & \multicolumn{4}{c}{ Individual sterols (as \% of total sterols) } \\
& Cholesterol & Campesterol & $\beta$-sitosterol & Stigmasterol \\
\hline Cigarette tobaccos & 9.70 & 16.38 & 33.96 & 40.07 \\
Butts & 9.45 & 17.17 & 33.58 & 39.39 \\
Papers removed from butts & 13.12 & 16.09 & 31.06 & 39.73 \\
Smoke condensate & 13.38 & 15.89 & 31.15 & 39.57 \\
\hline
\end{tabular}

takes place at the elevated temperature during smoking, it may leave some steryl glycosides intact. It appears that the relative amounts of 3 forms of sterols in cigarette tobacco probably influences the transfer into the smoke condensate.

GLC analysis of four sterols is shown in Table 3. A slight increase of cholesterol was found in trapped smoke condensates and wrapping paper from butts. The higher volatility of endogenous cholesterol in this study was in accord with the observation of higher transfer of ${ }^{14} \mathrm{C}$-labeled cholesterol than ${ }^{14} \mathrm{C}$-labeled $\beta$-sitosterol in cigarette tobacco smoke.

\section{SUMMARY}

Cholesterol-4- ${ }^{14} \mathrm{C}$ and $\beta$-sitosterol-4- ${ }^{14} \mathrm{C}$ were incorporated into cigarettes and their presence in mainstream smoke was studied. The transfer of ${ }^{14} \mathrm{C}$-labeled cholesterol to mainstream smoke was $20.27 \%$, of which $16.25 \%$ was in trapped smoke condensates and $4.02 \%$ in butts; only $0.004 \%$ was in ashes. The transfer of ${ }^{14} \mathrm{C}$-labeled $\beta$-sitosterol to mainstream smoke was $16.20 \%$, of which $13.11 \%$ was in trapped smoke condensates and $3.09 \%$ in butts; only $0.007 \%$ was in ashes. The relative composition of free sterols, steryl esters, and bound glycosides in cigarette tobacco and in trapped smoke condensates was also studied. Fractions of free sterols and steryl glycosides were higher while fraction of esters was lower in trapped rauch betrug $16,20 \% ; 13,11 \%$ waren im Rauchkondensat, 3,09\% im Stummel und nur $0,007 \%$ in der Asche enthalten. Im Cigarettentabak und im aufgefangenen Rauchkondensat wurde auch die relative Zusammensetzung an freien Sterinen, Sterylester und gebundenen Glykosiden untersucht. Im Vergleich zum Cigarettentabak waren im Rauchkondensat die Anteile der freien Sterine und Sterylglykoside größer und die der Ester kleiner. Die Gehalte an vier einzelnen Sterinen (Cholesterin, Campesterin, Stigmasterin und $\beta$-Sitosterin) im Cigarettentabak und im Cigarettenrauch (Kondensat, Stummel, Papier des Stummels) wurden miteinander verglichen. Eine leichte Zunahme des Gehaltes an Cholesterin wurde im Rauchkondensat und im Papier des Stummels festgestellt.

\section{RESUME}

On a incorporé du cholestérol-4- ${ }^{14} \mathrm{C}$ et du $\beta$-sitostérol$4^{-14} \mathrm{C}$ dans les cigarettes et étudié leur présence dans le flux principal de fumée. Le transfert du cholestérol marqué au ${ }^{14} \mathrm{C}$ était de $20,27 \%$ dans le flux principal de fumée, dont $16,25 \%$ dans le condensat de fumée récupérée et $4,02 \%$ dañs les mégots. On n'a trouvé que $0,004 \%$ dans les cendres. Le transfert du sitostérol marqué au ${ }^{14} \mathrm{C}$ était de $16,20 \%$ dans le flux principal de fumée, dont $13,11 \%$ dans le condensat de fumée récupérée et $3,00 \%$ dans les mégots. On n'a trouvé que $0,007 \%$ dans les cendres. La composition relative des stéroles libres, des esters stériliques et des gluco- 
sides liées a été étudiée également dans le tabac de cigarettes et dans les condensats de fumée récupérée. On a trouvé que les fractions de stéroles libres et de glucosides stériliques étaient plus élevées, et les fractions estérifiées moins élevées dans les condensats de fumée que dans les tabacs de cigarettes. On a étudié les proportions de quatre stéroles individuelles (cholestérol, campestérol, stigmastérol et 8 -sitostérol) dans le tabac de cigarettes et la fumée de cigarettes (condensats de fumée, mégots et papiers de mégots). Une légère augmentation de cholestérol a éte notée dans les condensats de fumée et les papiers de mégots.

\section{REFERENCES}

1. Stedman, R. L.: Chemical Rev, 68 (1968) 153.

2. Cook, C. E., M. E. Twine, and M. E. Wall: Experientia 23 (1967) 987.

3. Bolt, A. J. N., and R. E. Clarke: Phytodhem. 9 (1970) 819.

4. Rodgman, A., L. C. Cook, and P. H. Latimer: Tob. Science 3 (1959) 125.

5. Grunwald, C., D. L. Davis, and L. P. Bush: J. Agri. and Food Chem. 19 (1971) 138.
6. Touey, G. P., and R. G. Mumpower: Tobacco 144 (1957) 18.

7. Stedman, R. L., and W. Rusaniwskyj: Tob. Science 3 (1959) 44 .

8. Wall, M. E,, and E. G. Kelley: Anal. Chem. Ig (1947) 677.

9. Cheng, A. L. S., M. J. Kasperbauer, and L. R. Rice: Phytochem. 10 (197x) 1481.

10. Tso, T. C., and A. L. S. Cheng: Phytochem. xo (1971) 2133.

\section{Acknowledgments}

I wish to thank Mr. F. T. Sharpe, Jr., for the measurement of radioactivity.

The author's address:

Tobacco Laboratory, Plant Genetics and Germplasm Institute, Agricultural Research Center, ARS, U. S. Department of Agriculture, Beltsville, Maryland, 20705, U.S.A. 